\title{
An assessment of biomaterials for hip joint replacement
}

\author{
Ranjeet Kumar Singh $^{1 *}$, Swati Gangwar ${ }^{1}$ \\ ${ }^{1 *}$ Department of Mechanical Engineering, Madan Mohan Malaviya University of Technology, Uttar Pradesh, INDIA \\ "Corresponding Author: e-mail: sgme@ @mmut.ac.in, Tel +91-9235500689 \\ ORCID iDs: https://orcid.org/0000-0002-5158-2587 (Swati Gangwar)
}

\begin{abstract}
Hip replacement is a surgical process where natural hip joints are replaced by artificial hip joint that helps the human being for getting better lifestyle by reduction in the unavoidable pain and better leg movement. The selection of material and durability of the hip joint replacement are serious significance for the implantation, because it determines how load is transferred through the stem. In the selection of materials, various problems related to hip joint replacement are found like adverse tissue reaction, allergic reaction, wear and corrosion resistance etc. To overcome this problem one has to create different new biomaterial. This review gives brief description about the different biomaterial used for hip joint replacement.
\end{abstract}

Keywords: hip joint, biomaterials, polymer, wear

DOI: http://dx.doi.org/10.4314/ijest.v13i1.4S

Cite this article as:

Singh R.K., Gangwar S. 2021. An assessment of biomaterials for hip joint replacement, International Journal of Engineering, Science and Technology, Vol. 13, No. 1, pp. 25-31. doi: 10.4314/ijest.v13i1.4S

Received: December 1, 2019; Accepted: February 5, 2021; Final acceptance in revised form: March 31, 2021

This paper was earlier presented at the International Conference on Energy, Environment \& Material Sciences (ICE2M), 1-3 December 2019 and substantially improved for this Special Issue. Guest Editor: Dr. Sri Niwas Singh, Professor (HAG), Department of Electrical Engineering, Indian Institute of Technology Kanpur, 208016 (U.P.) India, former Vice-Chancellor, Madan Mohan Malviya University of Technology Gorakhpur (April 2017 to July 2020).

\section{Introduction}

Hip joint replacement is a process where total or part of natural hip joint replace by prosthetic hip joint in order to reduce or free from pain and improve leg movement. In the $21^{\text {th }}$ century design, development and manufacturing of materials which are using as prosthetic hip joint materials are great importance in research field. Approximate one million hip replacements carried out every a year. It is expected number of replacement in hip joint increase and double till 2025 (Cowie, Briscoe, Fisher, \& Jennings, 2018). Now a days, problem develop in hip joint with not only the aging population but it is also the younger population so researcher are more attention on develop new biomaterial. The goal of develop new biomaterials use in hip joint have more strength, more hardness but less wear. Biomaterials are defined as nonviable materials to interface with biological system to evaluate, treat or replace any tissue, organ or function of body (Eliaz, 2019). vitro wear of bearing biomaterials (Affatato, 2018). This load act on hip joint varies with changed activity of human body such as sitting, jogging, slipping and climbing on stairs etc.

In addition this type of load is cyclic nature and developed stress continuous on hip joint. When the people reaches old age then density of bone is decrease so friction between hip joint during motion produces large wear and tear. This type of wear leads to much more pain during walking, sitting as well as sleeping. Wear and biological reaction of wear particles play important role in durability of hip joint (Stratton-powell, Pasko, Brockett, \& Tipper, 2016). At this time hip joint replacement is required to getting the better quality of life without pain. This replacement does not give permanent solution but it improve the quality of life during 
certain period of time depend upon the weight, activity and age of human body. Biomaterials properties depends upon specific structure and type of tissue replaced (Mohammed, 2019). So the material researchers try to develop new bio-materials using metal, ceramic, polymer or combination of these material to increase durability of hip replacement with toxic response does not beyond certain acceptable limit.

\subsection{Structure of hip joint}

Hip joint contains femoral stem, femoral head, plastic liner and acetabular cup (Ghalme, Mankar, \& Bhalerao, 2016). An artificial is kind of prostheses (synthetic body part) that contain two or more component. It usually a stem which fit into the femur and at the top of stem a ball like structure fitting is known as femoral head. This femoral head fit into acetabular component. Plastic liner uses between femoral head and acetabular cup which provides a smooth gliding surface of the ball with minimum wear. In general, hip implant is similar to loading as real bone and it is also act as biocompatible.

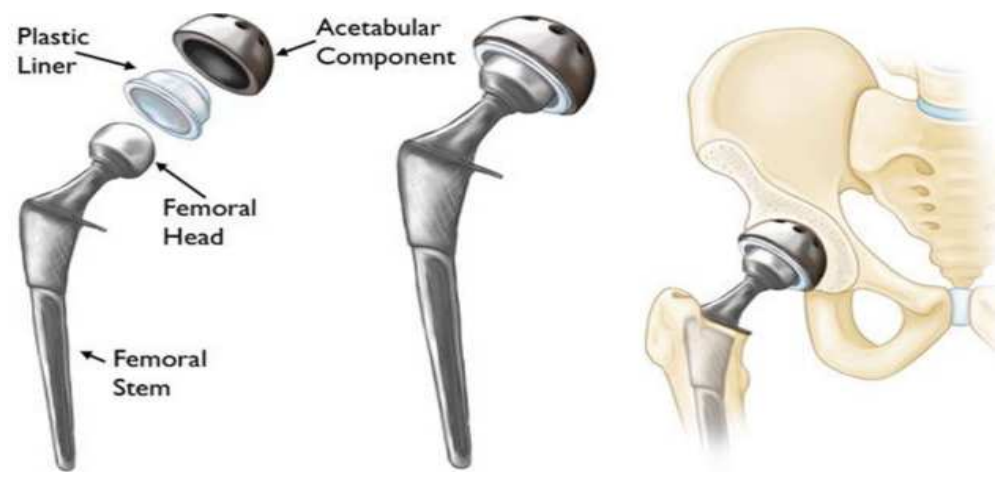

Figure 1. Different component of prosthetic hip joint(Ghalme et al., 2016)

The femoral stem for hip implant where outer layer should be porous structure help cell ingrowth in bone and internal cellular arrangement provide low stiffness and low weight. Outer surface for the femoral head in hip implant should be wear resistant and inner surface should be bioactive and low stiffness. Internal structure of acetabular component should be wear resistant and bioactive but outer structure of acetabular component provides strength to hip implant.

\subsection{Failure of hip joint implant}

Failure of implant material due to many reason such as insufficient hardness, wear resistance, yield strength and biocompatible. Insufficient hardness and wear resistance of material developed wear debris. This wear debris is main phenomena of implant failure. Insufficient yield strength of material give permanent deformation and this deformation increase contact stress. This high contact stress on hip joint is failure of implant. Low biocompatibility of materials can produce adverse effect and implant failure. Mechanical, biological and tribological effect related to failure of hip joint prosthesis summarized in Fig [2].

There are three factor must be known to predict the clinical success or failure in the implant are (Mckellop, Clarke, Markolf, \& Amstutz, 1981)-

(1) The wear rate of the material in the laboratory test. (2) The contact stress and sliding distance per year for the prosthesis in question. (3) The rate of debris production that the tissues can accommodate.

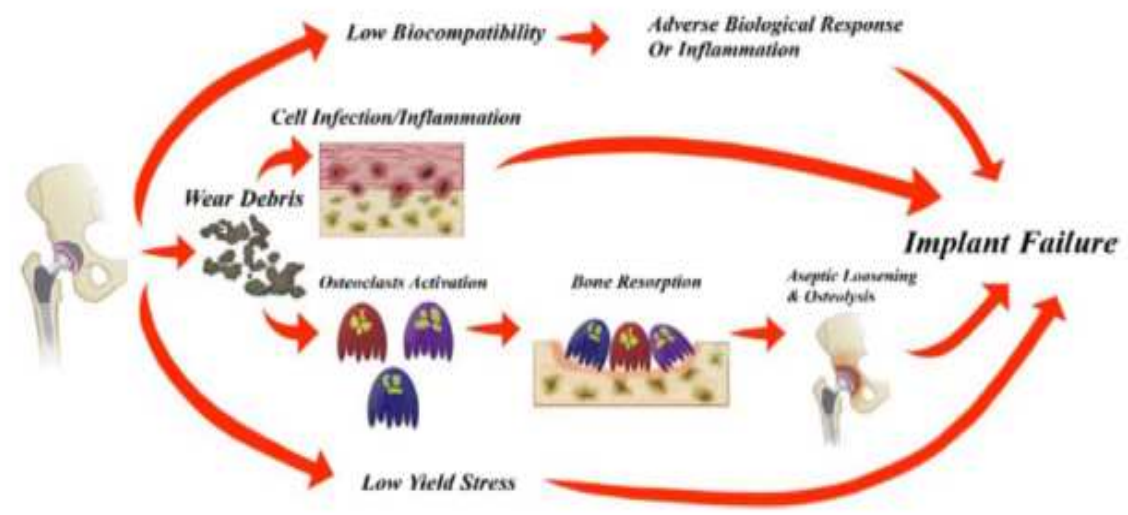

Figure 2. Mechanical, biological and tribological drawback of hip implant (Salari, 2019)

The biocompatible of hip joint materials include surface compatible, mechanical compatible and osteocompatibility (Ishihara, 2015). These types of materials are also classified as bioactive, bio-inert and biodegradable. Biomimetic surface amendment with 
fixing of hydrophilic polymer means polymer surface arranged radical polymerization. Advantage of photo induced radical graft polymerization; graft poly (MPC) provides high lubrication on the surface with no influence on the greater part of properties of the X-UHMWPE substrate. This type of grafting on X-UHMWPE substrate also provides oxidative stability and tremendous mechanical properties for long life hip joint prosthesis (Eliaz, 2019)(Mohammed, 2019).

\section{Materials use in bearing surface for hip joint replacement}

Bearing is made of different type of material and selection of bearing surface is very important for hip joint replacement. For hip joint replacement metal, ceramic, polymer or combination of these material use depend upon age, living standard and body weight. Selecting the bearing surface also depends upon durability, level of performance, performance level and your personal needs (https://www.elvisgrandicmd.com/hip-replacement/technology/bearing-surfaces, n.d.).

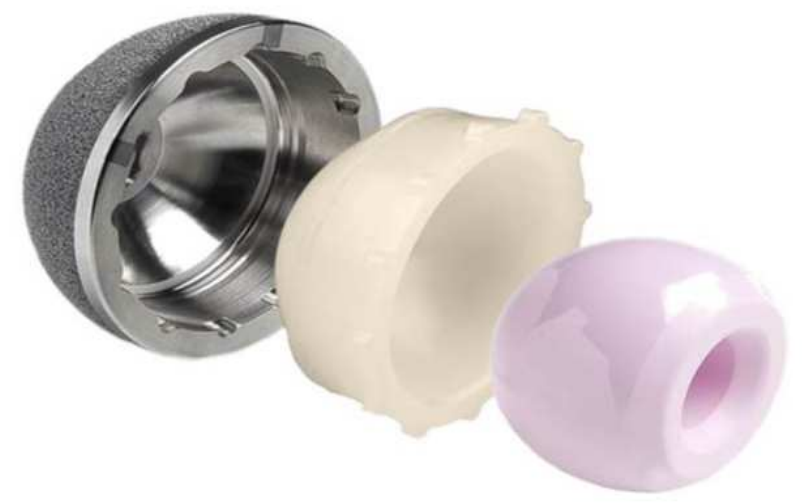

Figure 3. Bearing surface use in hip implant (internet source, n.d.)

Bearing couples means ball and socket joints where acetabular cup forms socket and head of femur bone rotates within the acetabular cup. During hip replacement surgery worn out acetabular component, femur head, or both may be replaced and these implants may be made up of different materials. Durability of hip joint bio-composite material mainly depends upon load bearing couple in hip joint replacement. The site at which the movable parts of new hip joint unite to form a movable joint is called as 'bearing'. Some literature work related to biomaterials in hip joint replacement shown in Table 1.

Table 1. Biomaterial for bearing couples in hip joint replacement

\begin{tabular}{|c|c|c|c|c|}
\hline Authors Name & Materials & $\begin{array}{l}\text { Fabrication and } \\
\text { Testing } \\
\text { equipments }\end{array}$ & Results & Applications \\
\hline $\begin{array}{l}\text { Shanawaz et } \\
\text { al. (Patil, Teja, } \\
\text { Naveen, \& } \\
\text { Syed, 2017) }\end{array}$ & $\begin{array}{l}\text { Polythelene/Titanium-oxide } \\
(5 \%, 10 \%, 15 \% \text { by weight })\end{array}$ & $\begin{array}{l}\text { Extruder } \\
\text { injection } \\
\text { moulding }\end{array}$ & $\begin{array}{l}\text { Tensile strength ,Flexural strength and Hardness increase } \\
\text { with increase percentage of reinforcement }\end{array}$ & $\begin{array}{l}\text { Orthopaedic } \\
\text { application such as } \\
\text { Bone fixation plates, } \\
\text { Hip joint } \\
\text { replacement, Bone } \\
\text { cement etc. }\end{array}$ \\
\hline $\begin{array}{l}\text { Wang et al. } \\
\text { (Aigno Wang, } \\
\text { Zongtao Zhang, } \\
\text { Daniel E. } \\
\text { Lawrynowiez, } \\
\text { n.d.) }\end{array}$ & $\begin{array}{l}\text { (1) Co-Cr on UHMWPE } \\
\text { (2) PEEK on UHMWPE }\end{array}$ & $\begin{array}{l}\text { Wear hip } \\
\text { simulator }\end{array}$ & $\begin{array}{l}\text { Average wear rate about } 84 \% \text { less in PEEK -on-UHMWPE. } \\
\text { Wear rate obtain in PEEK on UHMWPE is } 0.38 \\
\mathrm{~mm} 3 / \mathrm{million} \text { cycle where as in case of Co-Cr on UHMWPE } \\
\text { is } 2.41 \mathrm{~mm} 3 / \text { million cycle }\end{array}$ & Prosthetic hip joint \\
\hline $\begin{array}{l}\text { Wang et al. } \\
\text { (Kurtz, Ph, } \\
\text { Nevelos, \& Ph, } \\
\text { 2019) }\end{array}$ & $\begin{array}{l}\text { (1) Scratch Co-Cr on UHMWPE } \\
\text { (2)Scratch PEEK on UHMWPE }\end{array}$ & $\begin{array}{l}\text { Wear hip } \\
\text { simulator }\end{array}$ & $\begin{array}{l}\text { Average wear rate about } 89 \% \text { less in PEEK -on-UHMWPE. } \\
\text { Wear rate obtain in PEEK on UHMWPE is } 1.82 \\
\mathrm{~mm} 3 / \mathrm{million} \text { cycle where as in case of Co-Cr on UHMWPE } \\
\text { is } 16.67 \mathrm{~mm} 3 / \mathrm{million} \text { cycle }\end{array}$ & Prosthetic Hip joint \\
\hline $\begin{array}{l}\text { MeysamSalaril } \\
\text { et al. (Salari, } \\
\text { 2019) }\end{array}$ & $\begin{array}{l}\text { zirconia nano } \\
\text { particle/UHMWPE/hydroxyapatite }\end{array}$ & $\begin{array}{l}\text { Tensile, vicker } \\
\text { hardness and pin } \\
\text { on desk test }\end{array}$ & $\begin{array}{l}\text { Improve wear and mechanical properties such as tensile } \\
\text { strength and hardness. }\end{array}$ & $\begin{array}{l}\text { Liners of total hip } \\
\text { joint }\end{array}$ \\
\hline $\begin{array}{l}\text { Raelene M. } \\
\text { Cowie et al. } \\
\text { (Cowie et al., } \\
\text { 2018) }\end{array}$ & $\begin{array}{l}\text { UHMWPE-on-PEEK, and } \\
\text { for UHWMPE-on-cobalt chrome } \\
\text { bearing couples }\end{array}$ & pin-on plate test & $\begin{array}{l}\text { Decreasing friction with increasing protein } \\
\text { concentration. Increasing wear with increasing protein } \\
\text { lubricant concentration. Wear in UHMWPE-on-PEEK less } \\
\text { compare to cobalt chrome bearing couples. }\end{array}$ & Prosthetic Hip joint \\
\hline
\end{tabular}


Table 1 (Cont'd). Biomaterial for bearing couples in hip joint replacement

\begin{tabular}{|c|c|c|c|c|}
\hline Authors Name & Materials & $\begin{array}{c}\text { Fabrication and } \\
\text { Testing } \\
\text { equipments }\end{array}$ & Results & Applications \\
\hline $\begin{array}{l}\text { D. Duraccio et } \\
\text { al. (Duraccio et } \\
\text { al., 2019) }\end{array}$ & $\begin{array}{l}\text { UHMWPE/zirconium dioxide } \\
\text { ceramic reinforced with Alumina } \\
\text { (ATZ) }(2.5 \% \text { Wt. })\end{array}$ & & $\begin{array}{l}\text { Increase yield stress, Young modulus and hardness and also } \\
\text { Increase cell interaction hydrophobicity (viability and } \\
\text { adhesion). }\end{array}$ & $\begin{array}{l}\text { Prosthetic Hip joint, } \\
\text { finger joint, knee } \\
\text { joint }\end{array}$ \\
\hline $\begin{array}{l}\text { Steven M. } \\
\text { Kurtz et al. } \\
\text { (Kurtz et al., } \\
2019 \text { ) }\end{array}$ & PEEK-ON-CoCr & $\begin{array}{l}\text { Hip wear } \\
\text { simulator. }\end{array}$ & - & $\begin{array}{l}\text { PEEK is good } \\
\text { alternative for } \\
\text { femoral head at } \\
\text { place of metal and } \\
\text { ceramic }\end{array}$ \\
\hline
\end{tabular}

A polymeric material in hip joint prosthesis including two types of polymer where the first polymer is a natural or a synthetic polymer and the second polymer is modified lignin. The modified lignin is modified with an alkyl containing group via linker wherein the linker is an ether group or alkyl containing group is derived from fatty acid methyl ester (Carrick, 2019).

The prosthetic hip cup includes a porous metal at outer shell, preferably formed from fiber metal, and a compression moulded polyethylene component defining an articulating surface at its centre for contact with a prosthetic femoral head (Warner \& Gilbert, 1997).Serum lubrication is one of good choice to tested wear of prosthesis material at controlled body temperature (Biomechanics, 1981).

\subsection{Material for prosthetic cup (acetabular cup or polymeric cup)}

Linear actabular is the joint between femoral head and acetabular cup. Internal part of acetabular cup is known as plastic liner or polymeric cup (Santis, Gloria, \& Ambrosio, 2017).Generally, the biomaterials for polymeric cup of hip implant should be wear resistant whereas the biomaterial for outer surface should have more hard and more strength. Generally, femoral head and acetabular cup made for metal, ceramic or polymer to provide mechanical strength but repetitive and constant abrasion between these components of prosthetic hip implant generate the cytotoxic metallic wear debris. This wear debris generates adverse effect in human body and increase friction between femoral head and actabular cup. This phenomenon is main reason for implant failure. In order to minimize the wear effect and increase the durability of hip implant, linear actabular (also known as polymeric cup) is added in prosthetic hip implant. The pores portion of the polymeric cup received in an interface Strength between the polymeric cup and the backside which is significantly equal to the tensile Strength of the polymeric materials (Swarts, Rohr, Lin, Devanathan, \& Krebs, 1999). The back portion of porous construction describe interstitial pores where the pores being sized to receive a portion of the polymeric cup within and adapted for permitting ingrowth of the bone.

Ultra high molecular weight polyethylene (UHMWPE) is the maximum use as articulating surface in hip joint (Sakoda, Osaka, Uetsuki, Okamoto, \& Haishima, 2018). Wang et al. [15] gives hip simulator wear result and find out the volumetric wear rate of Co-Cr on UHMWPE cup is $2.41 \mathrm{~mm}^{3} /$ million cycles while PEEK (Poly ether-ether ketone) on UHMWPE cup is only 0.38 $\mathrm{mm}^{3} /$ million cycles. Means average wear rate about $0.84 \%$ less in PEEK on UHMWPE. Wang et al. also find out wear rate against scratched surface and find out UHMWPE against scratched PEEK head is about $1.82 \mathrm{~mm}^{3} / \mathrm{million}$ cycles while UHMWPE against scratched $\mathrm{Co}-\mathrm{Cr}$ head is $16.67 \mathrm{~mm}^{3} /$ million cycles. Means wear rate $89 \%$ less in UHMWPE against scratched PEEK head. So, author concludes an orthopedic prosthetic joint is a joint couple made of two bearing surfaces o generally, one is softer than other.

The effect of wear on lubricant temperature and different protein concentrations has been systematically examined on UHMWPE-on-PEEK and UHWMPE-on-cobalt-chrome bearing couples and conclude that wear factor for UHMWPE-on-PEEK is always less than UHWMPE-on-cobalt chrome at any temperature or at any protein concentration(Cowie et al., 2018). The wear factor and friction between materials of bearing couple increase with increase protein concentration (above $2 \%$ ) but wear factor decrease with increase temperature of lubricant (at elevated or room temperature).Ultra high molecular weight polyethylene (UHMWPE) normally used as bio-material for the prosthetic cup which is fitted into acetabular (Sakoda et al., 2018). The main drawback of this material wear debris originated from prosthetic cup and creep deformation. UHMWPE polyethylene wears and flows. Wear is due to surface properties, whilst creep is linked to bulk mechanical properties (Rieu, Pichat, \& Rabbe, 1991). Clinical acetabular components, fabricated from both ultrahigh molecular weight polyethylene (UHMWPE) and poly-tetra-fluoroethylene (PTFE) (Wang, Essner, \& Schmidig, 2003).

Carbon fibre reinforced polyether-ether-ketone (PEEK) and KELVAR fibre reinforce polyethylene use to increase strength and fatigue resistance (Kurtz et al., 2019). The main disadvantage of Carbon fibre reinforced polyether-ether-ketone (PEEK) against metal or ceramic is slightly more than polyethylene. KELVAR fibre reinforce polyethylene show debonding nature during cool down from processing temperature, reason is mismatch in thermo-elastic property. If using compression mouldings technique to fabricate composite material of KELVAR fibre (weight $10 \%$ and $20 \%$ ) reinforce polyethylene then elastic modulus close to bone and frictional behaviour close to HDPE. Zirconia has been also incorporated into Ultra high molecular weight polyethylene (UHMWPE) showed low wear compare to neat UHMWPE (Bhusari, Sharma, Bose, \& Basu, 2019). Graphene reinforced UHMWPE has been new proposed material for hip joint prosthesis. Advantage of Graphene reinforced UHMWPE increase hardness and yield strength but cell morphology and viability are not change. 


\subsection{Materials for femoral head}

Femoral head is upper end of thigh bone. The surface of femoral head and socket is lined by thick articulate cartilage and thin lined by synovial membrane. The ball of hip joint receives blood through the neck of bone. If any type damage in blood supplies then gradually death of cells in femoral head (femoral head is unidirectional blood supply). Due to death of bone formation and resorption, gradually the structure of bone in femoral head is weaker and starts to collapse (Https://orthopedichospital.blogspot.com/2015/11/avascular-necrosis-of-femoral-head.html, n.d.). After that AVN (Avascular necrosis) develop in head femur so the weight of bearing area of head is first place to collapse. Then rounded counter of femoral head loss and it became flattened causing abnormal movement in hip joint. Second osteoarthritis develops then gradually wears in ball and socket joints. The biomaterials for femoral head hip implant where outer surface should be wear resistant and inner surface should be bioactive and low stiffness. So the better choice biomaterial of inner surface femoral head is polymer based bio-composites and outer surface is metals or ceramics. Poly ether-ether ketone (PEEK) is a good choice of femoral head(Duraccio et al., 2019) . Material selection of femoral head is mainly depending upon the material of linear or acetabular cup [D]. PMMA with Grephene oxide or grephene is also a good alternative of femoral head (Paz, Forriol, Real, \& Dunne, 2017). Here both properties fracture toughness and fatigue property increase with increase grephene or grephene oxide. Grephene with PMMA have more fracture toughness and fatigue properties compare to PMMA with grephene oxide.

\subsection{Materials for hip stem}

The stem is a part of hip attached to the femur. This stem primarily substitutes the portion of cancellous bone, medullary canal and also femur head tissue[1]. Variation of mechanical stress act on prosthetic hip materials approximate same as natural femur in different condition and position of human. Approach of Stem fit into the canal is restoring the other joint and also dental crown. The femoral stem for hip implant where outer layer should be porous structure help cell ingrowth in bone and internal cellular arrangement provide low weight and stiffness. The choice of material for the hip stem also depends upon property of material. Most of mechanical damages in hip joint replacement are due to material fatigue (Nabrdalik \& Sobociński, 2019).

Fatigue resistance is one of the important properties for prosthetic hip stem material (Santis et al., 2017). Therefore, fatigue strength of prosthetic stem is higher than strength of bone. Other important property of prosthetic hip stem is stiffness. Stiffness of material is higher than stiffness of bone but large difference between stiffness of hip stem material and bone, produce stress shielding effect(Gibon et al., 2016). This effect leads to bone atrophy and aseptic loosing for long term period. Higher the stiffness of prosthetic stem, higher the remodelling so the higher value of bone loss (due to stress shielding effect)(Gibon et al., 2016). The elastic modulus of bones ranges between 5 and $30 \mathrm{GPa}$ depending on bone type and direction of measurement (Kocich, Lowe, \& Kunc, 2017). This stress shielding effect is not removed completely but it minimize. Another problem related to prosthetic stem is adverse tissue reaction, allergic reaction, corrosion resistance etc (Kurtz et al., 2019). Release of some specific ion form prosthetic stems material cause adverse tissue reaction and allogeneic responses.

Fiber reinforced composite materials for hip stem offer strength and more flexibility compare to metals (Santis et al., 2017). Here mechanical properties of hip stem are related to bone mechanical properties. Carbon fiber reinforcing thermoset resin such as epoxy is popular choice of composite prosthesis material. The searching other matrix biomaterial in composite for prosthesis stems are Poly-ether-ether-ketone (PEEK), poly-sulfone (PS), poly-ether-imide (PEI) etc. Increasing proximal stress transfer, hip stem material is more flexible compare to other part of hip joint. High mechanical and thermal resistance with negligible water absorption is important properties for hip stem biomaterials. Poly-ether-ether-ketone (PEEK) has tremendous material properties but serious processing condition(internet source, n.d.). Temperature sensitive semi-crystalline structure of PEEK is produce wide range of melting temperature. This type of behaviour is developed because of imperfection in crystallites and non-uniformity in their sizes. Hence controlling the processing temperature of PEEK fabrication is difficult process.

Poly-sulfone has shown drop of mechanical properties when saturated with Ringer's solution. Ringer's solution is solution of several salt dissolved in water for purpose of creating an isotonic solution (Sadiq, Black, \& Stack, 2014). Ringer's solution contains sodium chloride, potassium chloride, calcium chloride, sodium bi carbonate etc. It's generally uses to balance the $\mathrm{pH}$. Isotonic solution allows for free movement of water across membrane without change the concentration of solute. Poly-ethylimide (PEI) has excellent substrate of cell scattering and growth (internet source, n.d.). It has no cytotoxic reaction but resistance to sterilize (Completely clean or free for bacteria).PEI has also consider as matrix material reinforced with drop-off plies of glass and carbon fibre for designing a composite for hip stem with sufficient stability as well as mechanical properties.

\section{Conclusion}

The basic aim of developing alternative total THR (hip replacement materials) is to create a joint with low friction and low wear rate with increased strength. There is continues development of biomaterial from early days of polymer based composite material by using metal, ceramic and polymer. Every material has its advantages and disadvantage that must be considered during application. Ultra high molecular weight polyethylene (UHMWPE) has shown excellent wear resistant with better shock absorption compare to other type of polymer. Development of new biomaterials using ultra high molecular weight (UHMWPE) and poly-ether-ether-ketone (PEEK) has presented a very good alternative for hip joint replacement. The ideal total hip replacement (THR) material is still needed to be evaluated with the modifying metal surface, improving the polyethylene and 
developing polymer based composite materials. Addition of nanomaterial and other biomaterials in the UHMWPE and PEEK also presents the opportunity of development of future material for hip implant.

\section{Acknowledgment}

The authors are very grateful to the Madan Mohan Malaviya University of Technology Gorakhpur, India, for extending all possible help in carrying out this research work directly or indirectly.

\section{References}

Affatato, S. (2018). Towards wear testing of high demanding daily activities on total hip replacement : preliminary results. Journal of the Brazilian Society of Mechanical Sciences and Engineering, 40(5), 1-6. https://doi.org/10.1007/s40430-018-1185-6

Aigno Wang, Zongtao Zhang, Daniel E. Lawrynowiez, S.-S. Y. (n.d.). ORTHOPEDIC PAEK-ON-POLYMER BEARING. US 9,907,660 B2.

Bhusari, S. A., Sharma, V., Bose, S., \& Basu, B. (2019). HDPE / UHMWPE hybrid nanocomposites with surface functionalized graphene oxide towards improved strength and cytocompatibility.

Biomechanics, O. (1981). No Title, 10(4).

Carrick, C. (2019). Patent et Application, 1.

Cowie, R. M., Briscoe, A., Fisher, J., \& Jennings, L. M. (2018). Author's Accepted Manuscript Wear and Friction of UHMWPEon-PEEK. Journal of the Mechanical Behavior of Biomedical Materials. https://doi.org/10.1016/j.jmbbm.2018.09.021

Duraccio, D., Strongone, V., Malucelli, G., Auriemma, F., Rosa, C. De, Mussano, F. D., ... Faga, M. G. (2019). Abstract. Composites Part B. https://doi.org/10.1016/j.compositesb.2019.01.097

Eliaz, N. (2019). Corrosion of Metallic Biomaterials : A Review. https://doi.org/10.3390/ma12030407

Ghalme, S. G., Mankar, A., \& Bhalerao, Y. (2016). Biomaterials in Hip Joint Replacement, 4(2), 113-125. https://doi.org/10.17706/ijmse.2016.4.2.113-125

Gibon, E., Amanatullah, D. F., Loi, F., Pajarinen, J., Nabeshima, A., Yao, Z., ... Goodman, S. B. (2016). Review Article The Biological Response to Orthopaedic Implants for Joint Replacement: Part I: Metals, 1-12. https://doi.org/10.1002/jbm.b.33734

Https://orthopedic-hospital.blogspot.com/2015/11/avascular-necrosis-of-femoral-head.html. (n.d.). No Title.

https://www.elvisgrandicmd.com/hip-replacement/technology/bearing-surfaces. (n.d.). No Title.

internet source. (n.d.). No Title. Https://Www.Atlantaboneandjoint.Com/Hipreplacement.Html.

Ishihara, K. (2015). Highly lubricated polymer interfaces for advanced arti fi cial hip joints through biomimetic design, 47(9), 585-597. https://doi.org/10.1038/pj.2015.45

Kocich, R., Lowe, T. C., \& Kunc, L. (2017). Progress in Materials Science Advances in metals and alloys for joint replacement, 88, 232-280. https://doi.org/10.1016/j.pmatsci.2017.04.002

Kurtz, S. M., Ph, D., Nevelos, J., \& Ph, D. (2019). PEEK Bearing Materials for Total Joint Replacement. PEEK Biomaterials Handbook (2nd ed.). Elsevier Inc. https://doi.org/10.1016/B978-0-12-812524-3.00024-7

Mckellop, H., Clarke, I., Markolf, K., \& Amstutz, H. (1981). Friction and wear properties of polymer , metal , and ceramic prosthetic joint materials evaluated on a multichannel screening device, 15, 619-653.

Mohammed, M. T. (2019). Nanocomposites in total hip joint replacements. Applications of Nanocomposite Materials in Orthopedics. Elsevier Inc. https://doi.org/10.1016/B978-0-12-813740-6.00012-0

Nabrdalik, M., \& Sobociński, M. (2019). The finite element method in the analysis of the stress and strain distribution in polyethylene elements of hip and knee joints endoprostheses, 02025, 1-13.

Patil, S., Teja, S., Naveen, R. K. C., \& Syed, K. (2017). Evaluation of Mechanical Properties of Ultra High Molecular Weight Polyethylene Reinforced with TiO 2 Particles, 3(1), 130-139.

Paz, E., Forriol, F., Real, J. C., \& Dunne, N. (2017). PT. Materials Science \& Engineering C, (2016). https://doi.org/10.1016/j.msec.2017.03.269

Rieu, J., Pichat, A., \& Rabbe, L. M. (1991). Ion implantation effects on friction and wear of joint prosthesis materials, 12, 139143.

Sadiq, K., Black, R. A., \& Stack, M. M. (2014). Bio-tribocorrosion mechanisms in orthopaedic devices: Mapping the microabrasion - corrosion behaviour of a simulated CoCrMo hip replacement in calf serum solution. Wear, 316(1-2), 58-69. https://doi.org/10.1016/j.wear.2014.04.016

Sakoda, H., Osaka, Y., Uetsuki, K., Okamoto, Y., \& Haishima, Y. (2018). Evaluating the durability of UHMWPE biomaterials used for articulating surfaces of joint arthroplasty using delamination tests, 1-8. https://doi.org/10.1002/jbm.b.34095

Salari, M. (2019). I F E S sciences for life Improved wear, mechanical , and biological behavior of UHMWPE-HAp-zirconia hybrid nanocomposites with a prospective application in total hip joint replacement. Journal of Materials Science, 54(5), 4259-4276. https://doi.org/10.1007/s10853-018-3146-y

Santis, R. De, Gloria, A., \& Ambrosio, L. (2017). Composite materials for hip joint prostheses. Biomedical Composites (Second Edition). Elsevier Ltd. https://doi.org/10.1016/B978-0-08-100752-5.00012-3 
Stratton-powell, A. A., Pasko, K. M., Brockett, C. L., \& Tipper, J. L. (2016). The Biologic Response to Polyetheretherketone ( PEEK ) Wear Particles in Total Joint Replacement: A Systematic Review. Clinical Orthopaedics and Related Research ${ }^{\circledR}$, 474(11), 2394-2404. https://doi.org/10.1007/s11999-016-4976-z

Swarts, I. D. F., Rohr, W. L., Lin, S. T., Devanathan, T., \& Krebs, S. L. (1999). United States Patent ( 19 ), (19).

Wang, A., Essner, A., \& Schmidig, G. (2003). The Effects of Lubricant Composition on in Vitro Wear Testing of Polymeric Acetabular Components, (May), 45-52.

Warner, I. D. B., \& Gilbert, S. G. (1997). United States Patent ( 19 ) 45 Date of Patent :, (19).

\section{Biographical notes}

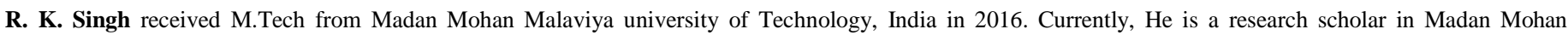
Malaviya university of Technology, India.

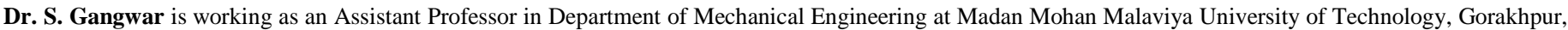

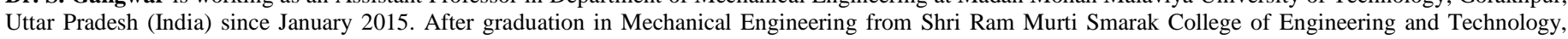

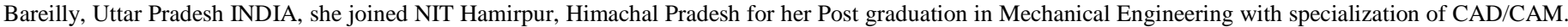

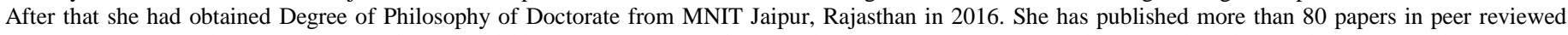

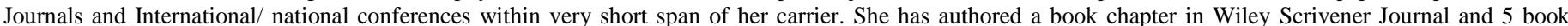

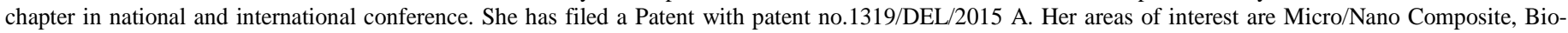
composites material, Tribology, Materials Characterizations, and Advance Manufacturing. 